\title{
"Methods of assessment of efficiency of creating regional innovative clusters for dynamic development of economics"
}

\begin{tabular}{|c|c|}
\hline \multirow{3}{*}{ AUTHORS } & Raisa Kozhukhivska (D http://orcid.org/0000-0003-4066-4170 \\
\hline & $\begin{array}{l}\text { Nataliya Parubok } \\
\text { Nataliya Petrenko (D https://orcid.org/0000-0003-0922-8389 }\end{array}$ \\
\hline & $\begin{array}{l}\text { Svitlana Podzihun } \\
\text { Irina Udovenko }\end{array}$ \\
\hline ARTICLE INFO & $\begin{array}{l}\text { Raisa Kozhukhivska, Nataliya Parubok, Nataliya Petrenko, Svitlana Podzihun } \\
\text { and Irina Udovenko (2017). Methods of assessment of efficiency of creating } \\
\text { regional innovative clusters for dynamic development of economics. Investment } \\
\text { Management and Financial Innovations, 14(3), 302-312. doi:10.21511/imfi.14(3- } \\
\text { 2).2017.01 }\end{array}$ \\
\hline DOI & http://dx.doi.org/10.21511/imfi.14(3-2).2017.01 \\
\hline RELEASED ON & Monday, 20 November 2017 \\
\hline RECEIVED ON & Tuesday, 15 August 2017 \\
\hline ACCEPTED ON & Tuesday, 03 October 2017 \\
\hline LICENSE & $\begin{array}{l}(c) \text { EY-NG } \\
\text { This work is licensed under a Creative Commons Attribution-NonCommercial } 4.0 \\
\text { International License }\end{array}$ \\
\hline JOURNAL & "Investment Management and Financial Innovations" \\
\hline ISSN PRINT & $1810-4967$ \\
\hline ISSN ONLINE & $1812-9358$ \\
\hline PUBLISHER & LLC "Consulting Publishing Company "Business Perspectives" \\
\hline FOUNDER & LLC "Consulting Publishing Company "Business Perspectives" \\
\hline
\end{tabular}

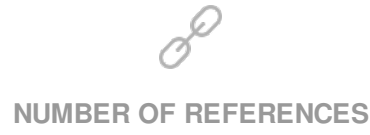

21

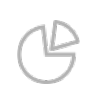

NUMBER OF FIGURES

1
$-=-$
$-=-5$

NUMBER OF TABLES

1

(C) The author(s) 2023. This publication is an open access article. 


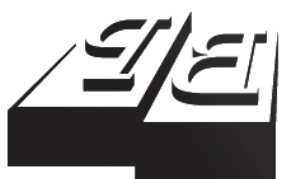

BUSINESS PERSPECTIVES

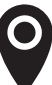

LLC "CPC "Business Perspectives" Hryhorii Skovoroda lane, 10, Sumy, 40022, Ukraine

www.businessperspectives.org

Received on: $15^{\text {th }}$ of August, 2017 Accepted on: $3^{\text {rd }}$ of October, 2017

(C) Raisa Kozhukhivska, Nataliya Parubok, Nataliya Petrenko, Svitlana Podzihun, Irina Udovenko, 2017

Raisa Kozhukhivska, Ph.D. (Economics), Associate Professor, Uman National University of Horticulture, Ukraine.

Nataliya Parubok, Ph.D. (Economics), Lecturer, Uman National University of Horticulture, Ukraine.

Nataliya Petrenko, Ph.D.

(Economics), Associate Professor

Uman National University of

Horticulture, Ukraine.

Svitlana Podzihun, Ph.D

(Economics), Associate Professor, Uman State Pedagogical University named after Pavlo Tychyna, Ukraine.

Irina Udovenko, Ph.D. (Economics), Associate Professor, Uman National University of Horticulture, Ukraine.

\section{(ㄷ)(1) $(8$}

This is an Open Access article, distributed under the terms of the Creative Commons Attribution-NonCommercial 4.0 International license, which permits re-use, distribution, and reproduction, provided the materials aren't used for commercial purposes and the original work is properly cited.

Raisa Kozhukhivska (Ukraine), Nataliya Parubok (Ukraine), Nataliya Petrenko (Ukraine), Svitlana Podzihun (Ukraine), Irina Udovenko (Ukraine)

\title{
METHODS OF ASSESSMENT OF EFFICIENCY OF CREATING REGIONAL INNOVATIVE CLUSTERS FOR DYNAMIC DEVELOPMENT OF ECONOMICS
}

\begin{abstract}
The deployment of a systemic economic crisis in Ukraine was conditioned by the aggravation of the socio-economic situation in certain regions and the build-up of structural deformations in the economy and the preservation of an inefficient model of production organization. This situation requires the search for a new model of economic growth, which is based on the use of competitive advantages of regions and a combination of industrial, scientific and managerial potential of the domestic economy.
\end{abstract}

Clustering is a form of internal integration that can provide both sustainability and a synergistic effect of counteracting global competition for today.

The research of the foundations of the formation of a modern cluster theory is a significant theoretical and practical interest for the further development of a successful model of cluster policy in Ukraine. In addition, the important place in this judgment is the fact that this theory is in the stage of active formation and development.

The purpose of the article is to study, analyze and develop the methods of assessment of efficiency of creating regional innovative clusters for dynamic development of economics. The article considers the methods of quantitative evaluation of clusters performance based on the analysis of effects of reducing transaction expenses, capital value, marketing expenses, innovation diffusion and employment of infrastructure in common.

It was established that the application of innovative cluster approach is one of the most efficient tools in the fulfillment of tasks of enterprise modernization and ensuring the development of innovative sectors of economy. Cluster effects for regional economies are relative and, in general, can be used for estimating total cluster effect.

The suggested variants of assessment of potential cluster effects will provide opportunities of carrying out a more complete cluster estimation and selection of the most efficient projects for increasing the efficiency of regional innovation clusters and dynamic development of economics.

\section{Keywords}

\section{JEL Classification}

\section{INTRODUCTION}

Under the conditions of intensification of transformation changes of regional economy of Ukraine, the application of methods of innovative clusters is acquiring more and more significance. This is conditioned by the renovation and increase of the efficiency of regional policy tools under the financial crisis and shortage of budgetary funds for supporting enterprises, increasing their competitiveness, etc. 
In our research, the attention is focused on the effects which influence the indices of efficiency, innovative activity and competitiveness of enterprises.

Systemic integration effects are developing due to the fact that enterprises form a cluster, begin carrying out a coordinated policy on the market of factors of production, in particular, in the sphere of formation and employment of market and innovative infrastructure, as well as a uniform marketing policy in relation to other enterprises which do not make up the cluster. The opportunity to coordinate the efforts and financial assets in the process of working out new technologies and their entering the market arises.

The application of innovative cluster approach is one of the most efficient tools in the implementation of tasks for enterprise modernization and ensuring the development of innovative sectors of economy. Therefore, the interest in the problem of cluster formation and analysis of their influence on innovative activity of enterprises in Ukraine is growing at present.

Despite a great number of researches into aspects of functioning of clusters in different regions, a problem of carrying out and analyzing empirical findings, which apply methods of clusters quantitative analysis including clusters effect assessment, exists nowadays.

\section{LITERATURE REVIEW}

Theoretical and practical aspects of clusters formation, functioning and development are elucidated in the works of Ukrainian and foreign scientists.

The author of modern cluster theory is Porter who was one of the first to use the technical term "cluster" to explain economic processes. In his theory, Porter synthesized and developed ideas formed by several areas of economic science, such as neoclassical, social, institutional. In his theory, Porter synthesized and developed ideas formed by several areas of economic science, such as neoclassical, social, institutional, supplementing their research results in the field of strategic management. In a compilation of his works "Competition", Porter (1998) examines clusters from the standpoint of competition theory and defines them as geographically focused groups of interconnected companies, specialized suppliers, service providers, firms in related industries, as well as organizations related to their activities (for example, universities, standardization agencies, trade associations) in a certain area that are competing but cooperative.

The basic concept of clusters is formulated by Porter (1998). It received significant development in the further research of many scholars who offered their own definition of the concept of "cluster" based on regional, social, foreign economic, innovation and other clustering effects.
Austrian researcher Bergman (1999) and American researcher Feser (1999) believe that a clustered approach to studying the economy of a particular territory allows to most accurately determine a comprehensive picture of the economic situation and specific features and connections for a particular region. According to researchers, it is the basis for the formation of an effective economic policy. They emphasize its role in shaping production and distribution chains in its definition of the economic essence of the cluster. An industrial cluster is defined as a group of commercial enterprises and non-profit organizations involved in sales agreements, joint technologies and distribution channels.

The scientific works of the Danish scientist Lundvall (1999) and later the American scientist Rosenfeld (2005) are devoted to the study of the benefits of social capital clusters. Thus, Lundvall (1999) described the growing importance of uncoded (implicit) knowledge in a rapidly changing global economic environment, defining the exchange of such knowledge as an important advantage of clustering firms.

Rosenfeld (2005) defines clusters as peculiar ecosystems that consist of interconnected groups of firms with a close geographic location. He argues that the localization of clusters is not limited to the administrative boundaries of states or regions, but is determined by the distance and time that 
the workers and management of the participating companies consider acceptable for the life of the companies.

Studies in the field of evolutionary-institutional theory of the Russian scientist Klejner (2008) have become a valuable contribution to the formation of a modern cluster concept. He considers the cluster as a multifunctional and multidimensional economic system that facilitates interaction between participants on the basis of cooperativeco-evolutionary arrangements, which ensures a balance between the independence of the cluster participants and their coordination. But Porter emphasized the decisive role of competition between companies in ensuring the efficiency of the organization of the economy.

Klejner (2008) considers the equally important factor in the co-evolution of economic systems and agents with their mutually enriching, coordinated evolutionary development. In his view, the importance of ensuring the security and integrity of the functioning of economic systems is growing significantly under current conditions. In this context, clusters can become peculiar "umbrellas" for participating companies that will ensure their safety and increase competitiveness.

The newest stage in the formation of a cluster theory, which began after 2000, was associated with the growing globalization of the economic space and the transition from sustained economic development to a nonlinear. It is based on innovation jumps. This has led to a number of studies on the role of clusters in the dynamics of economic growth through the creation of an environment conducive to the creation and commercialization of innovation.

There are many definitions of the concept of "innovation cluster" depending on the approach of different researchers to the understanding of innovation. So, some define an innovation cluster as an integral system of enterprises and organizations for the production of a finished innovative product, which includes the whole innovation chain from the development of a fundamental scientific idea to the production and distribution of finished products (Shovkaliuk, 2013).
Andersson et al. (2004) consider the innovation of clusters in a broader sense, involving the participation of cluster companies in the processes of technological, commercial and organizational innovation. The overwhelming majority of researchers share the view that the innovative effects of clusters are realized through the cooperation of the three leading institutional sectors - science (universities), business and government. These three agents are involved in the process of co-evolution in interaction, bringing their functional areas closer together, and provide a dynamic self-development of the cluster.

The process of cauterization is gaining strength not only in developed countries, but also in developing countries and in transition economics. The objective preconditions for the intensification of this process are subjective grounds for their further growth in the form of effective cluster strategies based on the centers of business activity. Cluster strategies are particularly widely used in European countries and serve as a new vector for the development of the world economy. The formal geographic boundaries of the cluster contribute to the special contacts and close interaction of agents of the domestic market, as well as stimulate the accumulation of social capital, the critical mass of which is the basis of innovation development (Kulishov, 2013).

However, the issue of methodological aspects and assessment of efficiency of creating regional innovative clusters for dynamic development of economics remains scantily studied at the moment.

\section{DATA AND METHODS}

Global experience of corporate economy management proves that there are several approaches to the assessment of cluster functioning efficiency. One of the most wide-spread approaches is the assessment of cluster synergy effect when the extended price of enterprises, which are the cluster's members, becomes bigger than the totality of their individual values. However, the application of such an approach is reasonable for assessing the efficiency of cluster formation when there is sustainable value appraisal of the cluster's enterprises performance. Therefore, as a first step, 


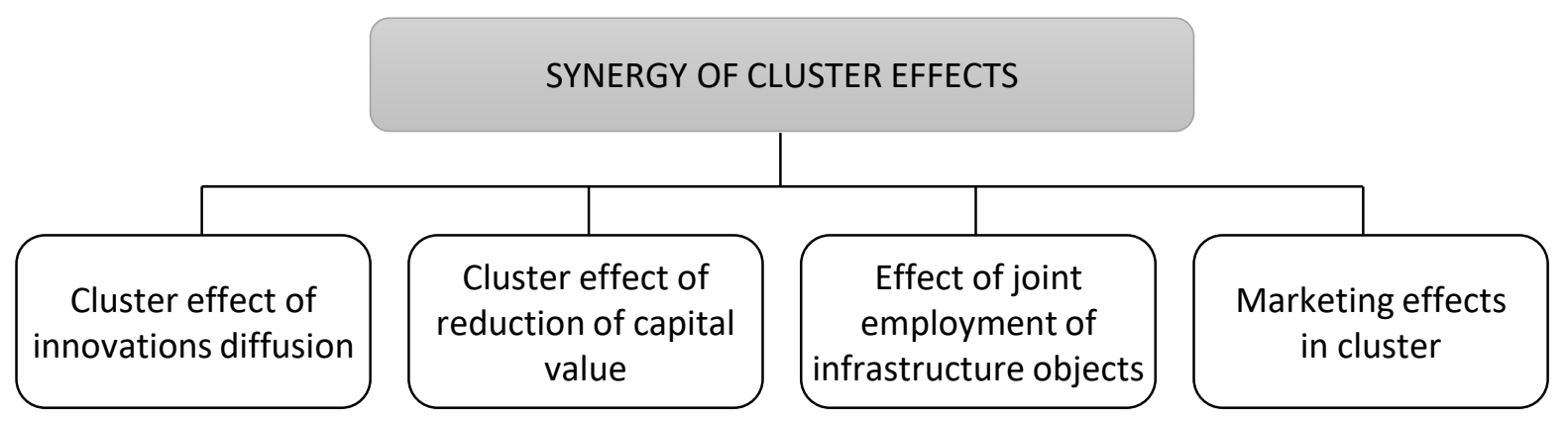

Figure 1. Synergy of cluster effects

it is necessary to analyze and estimate certain effects which appear in the process of synergy while forming a cluster.

Cluster effects are referred to the influence of all the enterprises, cluster members, on different final rates of performance in the region in a particular sphere of economic activity (Voynarenko et al., 2014).

In our research, the attention is focused on the effects which influence the indices of efficiency, innovative activity and competitiveness of enterprises.

In our view, the cluster enterprises performance is a fundamentally new type of efficiency which characterizes the transition from the principle of economic rationalization, which is achieved by the size of an enterprise, to a broader principle of strategic economy, which is based on mutual support of different cluster members.

Systemic integration effects develop due to the fact that enterprises form a cluster, begin carrying out a coordinated policy on the market of factors of production, in particular, in the sphere of formation and employment of market and innovative infrastructure, as well as a uniform marketing policy in relation to other enterprises which do not make up the cluster. The opportunity to coordinate the efforts and financial assets in the process of working out new technologies and their entering the market arises.

A sustainable system of informal relations of individual experts and managers, joint participation in scientific societies and associations, formation of general rules of business ethics is formed (Ansoff, 1989).

The analysis of theoretical and empirical findings allowed us to differentiate the following types of cluster effects (Figure 1).

Let us consider cluster effects and the assessment of budgetary efficiency and the efficiency of a cluster enterprise-member.

\subsection{Cluster effect of innovations diffusion}

The effect of the formation and development of regional clusters is the intensification of processes of innovation activities in clusters, due to the formation of stable relations between enterprises the processes of innovations diffusion and, as a consequence, the increase of enterprises competitiveness making up the cluster begin.

There is a great number of empirical works which concentrate on the studying of spatially limited diffusion of innovations and the importance of knowledge transfer for regional productivity and innovative activity (Lysyak, 2015).

The research of innovations diffusion is based upon the hypothesis that these processes lead to dynamic externalities and in geographic context, it resulted in agglomerative effects which together make it possible to explain objective laws of economic growth of regions (Voynarenko, 2014).

Herewith, the increase of income per capita appears due to the increase of level of knowledge 
in the region, which leads to the emergence and application of more effective production technologies. For foreign technologies to be successfully adapted and applied, the absorption of the ability of regional economy in the field of innovations and new technologies may depend on the educational level of employees, the level of development of national research enterprises.

Successful implementation of innovations can be promoted by the government policy which facilitates scientific research, availability of good universities with a network of scientists working there (Bushueva, 2012).

Consequently, favorable prerequisites for production, transfer and adaptation of new knowledge are formed in the regional innovation clusters, which include small and big enterprises, in coordination with universities and research centers. A special role in facilitating and speeding the innovations diffusion is played by a cluster social environment which consists of experts in different fields of knowledge in research centers, universities and enterprises. Such social environment creates a foundation for informal trust-based relations between new knowledge carriers making their communication process easier. The assessment of such kind of effects becomes evident in a long-term period. To estimate the effect of innovations diffusion processes in cluster development, we will build a model which evaluates the impact of the amount of fixed assets and education of a region residents on the level of their welfare.

Let us presume that total money income of the region's population in this way depends on the average annual number of people employed in economy, capital-labor ratio and average level of education of human capital assets:

$$
T=\text { Const } \cdot X_{i}^{A} \cdot Y_{i}^{B} \cdot e^{C z_{i}},
$$

where $T$ - total money income of the population in the $i$-region (UAH); $X$ - capital-labor ratio per 1 employee in the $i$-region (UAH/capital); $Y$ - average annual number of people engaged in economy in the $i$-region (people); $e$ - level of welfare; $Z$ - average level of education of human capital assets in the $i$-region (years); Nonst
- constant variable value for regression errors; $A, B, C$ - constant values for regression model.

The corresponding logarithm equation of regression is as follows:

$$
T=S_{\text {const }}+A \ln X_{i}+B \ln Y_{i}+C Z_{i}+\varepsilon_{i},
$$

where $\varepsilon_{i}$ is random remainder.

Table 1 shows the results of calculation of the regression equation based on the statistical data of the State Statistics Service of Ukraine with the application of methods of statistical verification of Student's and Fisher's hypotheses.

With independent variables all coefficients are statistically valid, coefficients of equation determination are high, they fluctuate from 95 to 97\%. Therefore, the selected independent variables determined from 95 to $97 \%$ of fluctuations of the dependent variables, that is, the amount of gross money income of the population of a region taking into account differences in the regions' size and level of development.

The table shows the results of computation of equations of multiple regressions. Herewith, while estimating the average level of education of human capital assets, the data of the State Statistics Service of Ukraine (2012-2015) on the structure of economically active population according to their education level were used, and the following terms of education were taken: higher education - 16 years; incomplete higher education - 14 years; specialized secondary education - 13 years; technical education - 12 years; general secondary education - 11 years; incomplete secondary education -9 years. On their basis, the assessment of the average level of education of the population of a region was carried out.

Coefficient A at the variable "Average annual number of people employed in economy" decreases with the course of time, which demonstrates the increase of influence of other factors on the population's gross income. Coefficient B at the variable "Capital-labor ratio" also drops with the course of time which proves the decrease of dependence of "Gross money income" on this factor. Coefficient $\mathrm{C}$ at the variable "Average level 
Table 1. Correlation between logarithms of gross money income, average annual number of people engaged in economy, capital-labor ratio and average level of education of human capital assets of different regions of Ukraine

Source: based on the authors' estimates according to the data of State Statistics Service of Ukraine (2012-2015), in the process of estimation, the data of the Eastern region of Ukraine and the republic of Crimea were not considered due to the lack of statistical data. Retrieved from http: //www.ukrstat.gov.ua

\begin{tabular}{|c|c|c|c|c|}
\hline Characteristic of regression model & 2012 & 2013 & 2014 & 2015 \\
\hline Const & 1.057 & 3.228 & 3.020 & 3.117 \\
\hline Standard error & 1.103 & 0.781 & 1.106 & 1.069 \\
\hline$T$ - Student's statistics & 0.96 & 4.13 & 2.73 & 2.92 \\
\hline$P-$ level & 0.34 & 0.0001 & 0.0078 & 0.0046 \\
\hline Coefficient $A$ & 1.040 & 1.033 & 1.030 & 1.012 \\
\hline Standardized rate $A$ & 0.9360 & 0.950 & 0.955 & 0.948 \\
\hline Standard error & 0.0280 & 0.022 & 0.026 & 0.023 \\
\hline$T$ - Student's statistics & 36.83 & 46.15 & 43.80 & 44.70 \\
\hline$P-$ level & 0.0000 & 0.0000 & 0.0000 & 0.0000 \\
\hline Coefficient $B$ & 0.3220 & 0.292 & 0.274 & 0.244 \\
\hline Standardized rate $B$ & 0.1910 & 0.194 & 0.187 & 0.170 \\
\hline Standard error & 0.0430 & 0.031 & 0.031 & 0.029 \\
\hline$T-$ Student's statistics & 7.53 & 9.48 & 8.78 & 8.50 \\
\hline$P-$ level & 0.0000 & 0.0000 & 0.0000 & 0.0000 \\
\hline Coefficient $C$ & 0.3380 & 0.220 & 0.272 & 0.310 \\
\hline Standardized rate $C$ & 0.1100 & 0.078 & 0.068 & 0.077 \\
\hline Standard error & 0.0790 & 0.059 & 0.088 & 0.086 \\
\hline$T-$ Student's statistics & 4.29 & 3.71 & 3.10 & 3.61 \\
\hline$P-$ level & 0.0001 & 0.0004 & 0.0027 & 0.0005 \\
\hline Determination coefficient & 0.9520 & 0.970 & 0.966 & 0.970 \\
\hline$F$ - Fisher's statistics & 506.4600 & 823.820 & 737.25 & 832.71 \\
\hline$P$ - level & 0.0000 & 0.0000 & 0.0000 & 0.0000 \\
\hline
\end{tabular}

of human capital assets" increases from 2013 to 2014 due to its significance having achieved influence on gross population's income by 2015.

It is possible to assess the effect of creating a cluster, which evolves due to the concentration of enterprises and highly educated experts in a particular locality with the help of a developed and computed model in the following way:

$$
T=3.117 \cdot X \cdot Y_{i}^{0.244} \cdot e^{0.31 z_{i}}
$$

It is possible to receive the amount of gross income of the cluster employees placing the assumed number of people employed at the cluster enterprises, average capital-labor ratio of employees and their education level into the formula. Its comparison with the existing level of income allows to evaluate the increase of the welfare of the regional population employed at the cluster enterprises. Therefore, the efficiency of creating a cluster for regional authorities manifests itself in the increase of income of regional population. The developed model has a high determination coefficient which makes it possible to consider a cluster as a meso-economic system along with the regional economy. The conducted analysis showed that the role of knowledge and education level in the economy of Ukraine is noticeable and rather big, and authorities need to concentrate the investments in the education of regional growth areas - potential innovation 
clusters, ensuring the increase of gross income of population, the level of actual final consumption and creating the foundation for scientific and technical development and innovations diffusion.

\subsection{Cluster effect of decreasing the cost of capital}

Availability of financial resources, on the one hand, makes it possible to develop new projects of cluster enterprises and, on the other hand, it promotes the increase of financial sustainability of all enterprises of the cluster. Under the conditions of strengthening economic ties, regional clusters become attractive for foreign investments, cluster enterprises have lower market risks and eventually their competitiveness increases. Broadening the array of financial tools used in the system of regional management of cluster entities which includes attracting the capital of strategic investors and international financial enterprises, activating leasing operations leads to the reduction of the cost of capital of cluster enterprises.

The cost of capital shows the level of return on the invested capital, the index integrates the information on a particular structure of the formed capital elements, their individual value and significance in the total capital amount.

$$
W A C C=I_{c o c} \cdot K_{s o c}+L_{c l c} \cdot N_{\mathrm{slc}} \cdot\left(1-i_{t r}\right) \text {, }
$$

where WACC - cost of capital; $I_{c o c}$ - cost of owner capital (\%); $K_{s o c}$ - share of owner capital (\%, according to balance); $L_{c l c}-$ cost of loan capital (\%); $N_{\text {slc }}$ - share of loan capital (\%, according to balance); $i_{t r}$ - income tax rate (\%).

The main problem in calculating $W A C C$ index lies in the assessment of the price of capital unit received from a particular source of funds as the accuracy of calculating WACC depends on it. It may be calculated rather easily and accurately for some sources (for example, the cost of a bank loan); it is quite difficult to do it for a number of other sources, what is more, accurate calculating is impossible. Nevertheless, even approximate $W A C C$ calculations are acceptable for analytical purposes.
The assessment of cluster effect of increasing the supply of capital and decreasing its cost is possible in the following way:

$$
\begin{gathered}
E_{a e}=F \cdot \Delta W A C C, \\
E_{b e}^{a e}=i_{e t r} \cdot \sum E_{a e}=i_{e t r} \cdot \sum(K \cdot \Delta W A C C),
\end{gathered}
$$

where $E_{a e}$ - annual effect of decreasing the cost of capital; $F$ - amount of aggregate enterprise capital; WACC - cost of capital; $E_{b e}^{a e}$ - budgetary effect of decreasing transaction expenses; $i_{\text {etr }}$ efficient tax rate at enterprises.

It should be mentioned that the presented method of assessment provides only evaluation of the potential effect; more accurate data can be received when having information on the amount of external investments, their structure and conditions. In general, the formation of regional innovative clusters creates special conditions for the development of the system of projects venture financing, in particular, for the growth of innovation movement, attracting attention of venture funds to the region and creation of centers of consulting services for appropriate elaboration of projects.

\subsection{Effect of joint use of infrastructure objects}

This kind of synergy is a result of joint use of specialized production assets, scientific equipment, premises and engineering structures by cluster enterprises. As a rule, solving problems of managing the infrastructure investments is the competence of the state. However, in recent times, the role of private and government partnership projects in creating infrastructure, as well as, in exceptional cases, in creating infrastructure objects totally by means of private funds with the help of collective investing is increasing.

Infrastructure is the foundation, based on which the competitive advantage of a cluster is formed (Tarasenko, 2015).

In the current context, clusters in Ukraine do not have historical characteristics of development, therefore, this is the availability of infrastructure, 
at any extent of development, which is the foundation based which cluster interrelationships are built (Lindqvist et al., 2013). In this case, production infrastructure is meant. Besides, the availability of production infrastructure facilitates creating new enterprises basing on the existing opportunities for development. Currently, more and more attention is paid to the development of infrastructure. At present, according to the data of Ministry of Economic Development and Trade of Ukraine, about 100 regional institutions of development have been formed in Ukraine. They provide support to infrastructure and innovation investment projects. However, the creation of infrastructure has been carried out sporadically; the strategies of development of target enterprisesmembers have been absent. Consequently, a great part of innovation infrastructure is used ineffectively or inappropriately.

In the process of investing in the elements of infrastructure complexes, it is more reasonable to take into account the functioning of the whole complex of enterprises-members and their interrelationships (Porter, 1998).

From this perspective, such kind of activity as infrastructure design, that is, purposeful practices in the modeling of an array of infrastructure project elements in order to achieve a maximum effect of their cooperation on all stages of the project realization is becoming actual (Illiashenko, 2014).

In general, this is a new principle of creating innovative infrastructure objects which implies the analysis of the environment, implementation of capability and remuneration of disadvantages of regional economic system. Therefore, designing innovative infrastructure can be defined as a process which transforms requirements of investors and entrepreneurs into the established characteristics of innovative infrastructure which results in creating efficient and requested objects which contribute to the growth of high-tech industries of regional economy. In the process of forming a cluster, the assessment of effects for enterprises and budget with consideration of the creation and use of infrastructure can be carried out as described below.

\section{RESULTS AND DISCUSSION}

\subsection{The assessment of the efficiency for authorities as a return on budget investments from the creation of infrastructure}

$$
E_{b e}^{a e}=\frac{\Delta G}{\sum E}=\frac{i_{e t r} \cdot\left(\sum \Delta P+\sum P_{n}\right)}{\sum E},
$$

where $E_{b e}^{a e}$ - budgetary efficiency of decreasing transaction expenses; $\Delta G$-growth of tax revenues to the budget; $E$ - expenses on the creation of infrastructure objects; $i_{\text {etr }}$ - effective tax rate for enterprises; $\Delta P$ - increase of profit of enterprises with an object of infrastructure being created; $P_{n}-$ profit of newly established enterprises as a result of creating an infrastructure object.

In absolute terms, budgetary efficiency of infrastructure creation can be calculated in the following way:

$$
\begin{aligned}
& E_{b e}^{a e}=\sum \Delta G-\sum E=\sum i_{e t r} \times \\
& \times\left(\sum \Delta P+\sum P_{n}\right)-\sum E .
\end{aligned}
$$

Herewith, in estimating the efficiency of capitalintensive infrastructure object, it is reasonable to calculate the increase of the amount of tax payments to the budget in mid-term and longterm perspective discounting corresponding sums.

\subsection{The assessment of the efficiency for cluster enterprises as a reduction of expenses for infrastructure creating and maintaining}

Let us assume that enterprises-members of a regional innovation cluster are interested in producing (or gaining) some "public benefit" product or service. In this case, the term "public" means that each cluster member can take the advantage of this benefit. It is understood that each enterprise-member will receive certain profit from the consumption. 
The cost (price) of such benefit is fixed and it is higher than the financial capacity of each individual enterprise, that is why it is necessary for the enterprises to unite their investment opportunities in order to acquire the benefit (Shovkaliuk, 2013).

Regardless of the method of distribution of expenses among enterprises-members, the efficiency for each of them will be calculated as follows:

$$
Q_{\mathrm{inf}}=\Delta P-E_{c e},
$$

where $Q_{\text {inf }}$ - efficiency of creating infrastructure for cluster enterprises; $\Delta P$ - additional enterprisemember's income from using the created public benefit; $E_{c e}$ - cluster member's expenses due to contribution payments for obtaining the public benefit.

In these circumstances, budgetary efficiency of obtaining public benefits by cluster enterprises with the help of their own corporate investments can be calculated in the following way:

$$
E_{b e}^{a e}=i_{e t r} \cdot\left(\sum \Delta P+\sum E_{c e}\right)
$$

The implementation of a project can be carried out in compliance with the concept of a cluster (Enright, 2000). In this case, a cluster is able to realize a synergy effect of using infrastructure that is multiplicatively increasing the volume of production.

Innovative cluster infrastructure can become an accelerator of fulfillment of progressive structural transformations in the economy and development of the scientific-industrial potential of a region (Boronos, 2017). Consequently, the process of designing the necessary infrastructure in a cluster should consider the size of synergy effects in clusters in the process of choosing priority projects and kinds of infrastructure under formation.

\subsection{Marketing effects in a cluster}

In the process of conducting cluster policy in the sphere of marketing communications, the employment of two main strategies, the creation of a single brand of a cluster or focusing on the promotion of a brand of an enterprise which is a cluster core, is observed. The improvement of brand and image characteristics of a cluster as a whole or its individual key economic entities (cores) facilitates the reduction of expenses on advertising due to the use of a corporate brand.

Popularity of the brand of the enterprise-cluster core provides ample opportunities for promoting brands of enterprises-suppliers and components based on the brand of the main cluster enterprise (Kniazieva, 2015).

In this connection, while creating a cluster, the marketing effect for the cluster enterprise and budget can be estimated as follows:

$$
E_{\text {erm }}=\Delta S_{r e t}+\Delta K
$$

$E_{b e}^{m e}=i_{e t r} \cdot\left(\sum \Delta S_{r e t}+\sum \Delta R+\sum K\right)$,

where $E_{\text {erm }}$ - effect of reducing marketing costs in the cluster; $\Delta S_{\text {ret }}$ - reduction of each type of marketing expenses; $\Delta K$ - growth of the amount of sales of cluster enterprises as a result of brand promotion or brand use; $E_{b e}^{m e}$ - budgetary efficiency of reducing marketing expenses in the cluster; $R$ - revenues of newly formed cluster enterprises; $i_{\text {etr }}$ - efficient tax rate for enterprises.

It is necessary to admit that in the process of creating a cluster the reduction of marketing expenses does not always take place. In some cases, especially when the cluster under formation creates a new brand, expenses of all the enterprises may increase, and then cluster effects become evident in the long term with the growth of total income and income of enterprises-members of the cluster.

\section{CONCLUSION}

In modern economic conditions, the issue of assessment of efficiency of creating and functioning of clusters is acquiring special significance. 
During our research into the methods of estimating the efficiency of creating regional innovation clusters for dynamic development of economics, it was established that the application of an innovative cluster approach is one of the most efficient tools in the process of fulfilling the tasks of enterprises modernization and ensuring the development of innovative sectors of economy.

The external effect for regional authorities is the increase of the taxation basis due to locating additional enterprises in the region and intensification of innovation processes, reduction of prime cost of the produced output, increase of profitability and improvement of socio-economic situation for the population of the region.

The cluster effects for regional economy considered in the article (namely, budgetary efficiency and social effects) are relative and, in general, can be used for estimating the total cluster effect.

At present, due to overcoming consequences of the financial crisis and the possibility of another manifestation of crisis phenomena in the economy of Ukraine as well as the lack of progress in modernization of innovative development, the need for more qualitative selection of regional development projects, potential "points of growth", has grown considerably in order to support them.

The suggested variants of assessment of potential cluster effects will provide opportunities of carrying out a more complete cluster estimation and selection of the most efficient projects for increasing the efficiency of regional innovation clusters and dynamic development of economics.

The modern cluster theory has absorbed the results of many years of research on the theory of regional economics, organization of economics, theory of innovation development and strategic management. Significant contribution was made by the researchers to form a modern understanding of clusters as points of economic growth, centers of technological, innovation and industrial development that contribute to the economic development of individual regions and the country as a whole, as well as understanding the role of the state in shaping such growth points.

Taking into account the considerable experience of foreign and domestic scientists and the dynamic development of modern cluster theory, further research in this direction will allow to identify priorities and formulate tasks for the successful implementation of cluster policy in Ukraine.

\section{REFERENCES}

1. Andersson, T., Schwaag-Serger, S., Sörvik, J., Wise Hansson, E. (2004). The Cluster Policies White Book. IKED, Sweden.

2. Ansoff, I. (1989). Strategic Management, Economics. Moscow, Russia.

3. Antonova, N. I., Markina, Y. D., \& Bakhmatova, G. A. (2015). Model of the Organizational Economic Mechanism of Sanitation and Sustainable Development of Problematic Rural Territories. Scientific Review, 9, 295-298.

4. Bergman, E. M., Feser, E. J. (1999). Industrial and Regional Clusters: Concepts and Comparative
Applications. Retrieved from http:// www.rri.wvu.edu/WebBook/ Bergman-Feser/contents.htm

5. Boronos, V. H. (2017). Методологічні принципи фінансового потенціалу територій [Metodolohichni pryntsypy finansovoho potentsialu terytorii]. Sumy: Sumy State University.

6. Bushueva, M. A. (2012). Синергия в кластере [Sinergiya v klastere]. Naukovedenie. Retrieved from http://cyberleninka.ru/ article/n/sinergiya-v-klastere

7. Derzhavna sluzhba statystyky Ukrainy (2012). Валовий грошовий дохід, середньорічна чисельність зайнятих в економіці, людський капітал у 2012-2015 pp. [Valovyi hroshovyi dokhid, serednorichna chyselnist zainyatykh v ekonomitsi, lyudskyi kapital u 2012-2015 rr.]. Retrieved from http: //www.ukrstat.gov.ua

8. Enright, M. J. (2010). Survey on the Characterization of Regional Clusters: Initial Results (Working Paper, Institute of Economic Policy and Business Strategy: Competitiveness Program, University of Hong Kong).

9. Kastels, M. (2010). The information age: economy, society 
and culture. Retrieved from http:// www.gumer.info/bibliotek_Buks/ Polit/kastel/03.php

10. Klejner, G. B., Kachalov, R. M., Nagrudnaja, N. B. (2008). Synthesis of cluster strategy on the basis of system integration theory. Industrial Organization, 5-6.

11. Knyazeva, O. A., Masliy, N. D. (2015). Мотиви та цілі інтеграційних процесів на різних економічних рівнях [Motyvy ta tsili intehratsiynykh protsesiv na riznykh ekonomichnykh rivnyakh]. Naukovyi visnyk Khersonskoho derzhavnoho universytetu.

12. Kulishov, V. V. (2013). Кластер основа інноваційного розвитку економіки [Klaster - osnova innovatsiynoho rozvytku ekonomiky]. Innovatsiina ekonomika. Retrieved from http://nbuv.gov.ua/UJRN/ inek 2013_2_2

13. Lindqvist, G., Ketels, Ch., Solvell, O. (2003). The Cluster Initiative Greenbook 2.0. Stockholm: Ivory Tower Publishers. Retrieved from https://www.hhs.se/contentassets/ f51b706e1d644e9fa6c4d232abd09e63/greenbooksep03.pdf
14. Lundvall, B. (1999). From Fordism to the globalising learning economy-implications for innovation policy (pp. 4-12). Paper presented at International Seminar on Learning Economy, Vienna, Austria, 21 June, 1999.

15. Lysiak, L. (2015). Бюджетна складова реалізації домінантних напрямів суспільного розвитку [Byudzhetna skladova realizatsiyi dominantnykh napryamiv suspilnoho rozvytku]. Dnipropetrovsk: DDFA.

16. Ministry of Economic Development and Trade of Ukraine (2017). Retrieved from www. me.gov.ua Porter, M. E. (1998). Clusters and the new economics of competition. Harvard Business Review, 76(6), 77-90.

17. Porter, M. E. (1998). On Competition. Harvard Business School, Boston, USA.

18. Rosenfeld, S. (2005) Industry Clusters: Business Choice, Policy Outcome, or Branding Strategy? Journal of New Business Ideas and Trends, 3(2), 4-13.
19. Shovkalyuk, V. S. (2013). Інноваційний розвиток України: особливості 2012 року [Innovatsiinyi rozvytok Ukrainy: osoblyvosti 2012 roku]. Nauka Ukrainy u svitovomu prostori. Retrieved from http://www.nas.gov.ua/publications/books/series/9789660247048/ Documents/2013_7/Nauka_Ukr_ V7_4.pdf

20. Tarasenko, V. (2015).

Территориальные кластеры: семь инструментов управления [Territorialnyie klastery: sem instrumentov upravleniya]. Moscow: Alpina Publishers.

21. Voynarenko, M. P., Bohatchyk, L. А. (2014). Використання кластерного інструментарію при розробці субрегіональних стратегій підвищення конкурентоспроможності економіки регіонів [Vykorystannia klasternoho instrumentariyu pry rozrobtsi subrehionalnykh stratehiy pidvyshchennya konkurentospromozhnosti ekonomiky rehioniv]. Aktualni problemy ekonomiky. Retrieved from http://nbuv.gov.ua/UJRN/ ape_2014_8_22 